\title{
A conceptual synthesis of organisational transformation: How to diagnose, and navigate, pathways for sustainability at universities?
}

Citation for published version (APA):

Baker-Shelley, A., van Zeijl - Rozema, A., \& Martens, P. (2017). A conceptual synthesis of organisational transformation: How to diagnose, and navigate, pathways for sustainability at universities? Journal of Cleaner Production, 145, 262-276. [Journal of Cleaner Production 145 (2017) 262e276]. https://doi.org/10.1016/j.jclepro.2017.01.026

Document status and date:

Published: 01/03/2017

DOI:

10.1016/j.jclepro.2017.01.026

Document Version:

Publisher's PDF, also known as Version of record

Document license:

Taverne

Please check the document version of this publication:

- A submitted manuscript is the version of the article upon submission and before peer-review. There can be important differences between the submitted version and the official published version of record.

People interested in the research are advised to contact the author for the final version of the publication, or visit the DOI to the publisher's website.

- The final author version and the galley proof are versions of the publication after peer review.

- The final published version features the final layout of the paper including the volume, issue and page numbers.

Link to publication

\footnotetext{
General rights rights.

- You may freely distribute the URL identifying the publication in the public portal. please follow below link for the End User Agreement:

www.umlib.nl/taverne-license

Take down policy

If you believe that this document breaches copyright please contact us at:

repository@maastrichtuniversity.nl

providing details and we will investigate your claim.
}

Copyright and moral rights for the publications made accessible in the public portal are retained by the authors and/or other copyright owners and it is a condition of accessing publications that users recognise and abide by the legal requirements associated with these

- Users may download and print one copy of any publication from the public portal for the purpose of private study or research.

- You may not further distribute the material or use it for any profit-making activity or commercial gain

If the publication is distributed under the terms of Article $25 \mathrm{fa}$ of the Dutch Copyright Act, indicated by the "Taverne" license above, 
Review

\title{
A conceptual synthesis of organisational transformation: How to diagnose, and navigate, pathways for sustainability at universities?
}

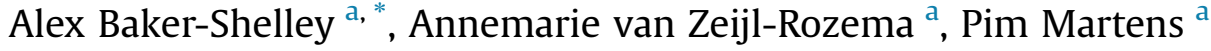 \\ a International Centre for Integrated Assessment \& Sustainable Development (ICIS), Maastricht University, Kapoenstraat 2, P.0. Box 616, 6200 MD, \\ Maastricht, The Netherlands
}

\section{A R T I C L E I N F O}

\section{Article history:}

Received 4 February 2016

Received in revised form

30 December 2016

Accepted 5 January 2017

Available online 13 January 2017

\section{Keywords:}

Organisational transformation

Sustainability in higher education

Socio-ecological systems

Social \& environmental responsibility

Behavioural change

\begin{abstract}
A B S T R A C T
Universities will play a profound role in a century in which society will be judged by its capacity for selftransformation in response to pandemic crises of climate change and capitalism. Frameworks of analysis of sustainability in organisations could benefit from tangible systemic rubrics for transformation. This research delineates core elements of organisational transformations for sustainability at universities. Criteria were woven into a framework that has value as a diagnostic tool, spanning three scales and five theoretical perspectives: behavioural science, corporate governance and responsibility, organisational change management, socio-ecological systems and sustainability in education and research. This was geared towards what organisational transformation for sustainability entails with universities specifically, if leverage points can be identified, and what the moral imperatives are of universities pursuing sustainability transformation. The orientation was to deduce distinct 'rules of the game' to diagnose organisational transformations for sustainability through descriptive and prescriptive criteria. The findings suggest high capacity for organisational transformation involves extroverted engagement, where potential rubrics help standardise comparison of environmental social governance issues in similar cultural and regional contexts. Students, academics, researchers and practitioners co-create knowledge in a 'republic of stakeholders', through a dialogical process of organisational-societal learning. Internally, an integrated approach, cross-linking information and disciplines from a network of actors has benefits for psychological wellbeing. Criteria for diagnosis could be formulated into an instrument through testing the analytical framework in transdisciplinary research cases. Future research might well focus on institutional differentiation and evolution of public research universities that navigate departures from traditional models, co-creating in reflexive iterations to achieve leverage for sustainability transformation.
\end{abstract}

(๑) 2017 Elsevier Ltd. All rights reserved.

\section{Contents}

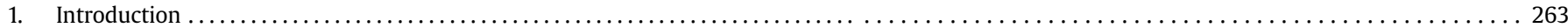

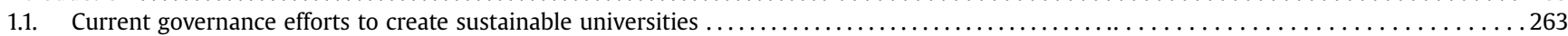

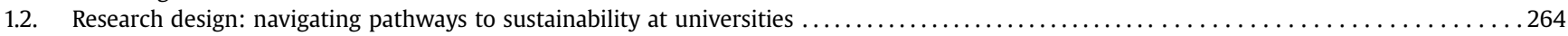

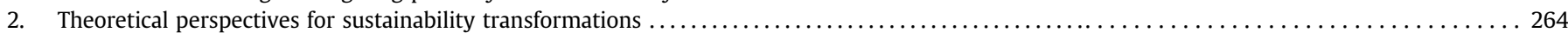

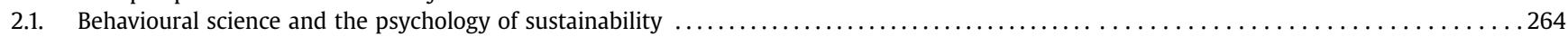

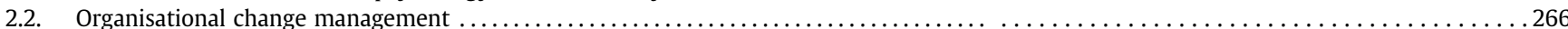

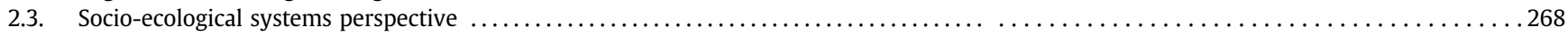

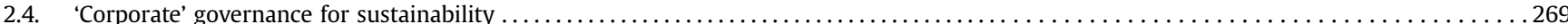

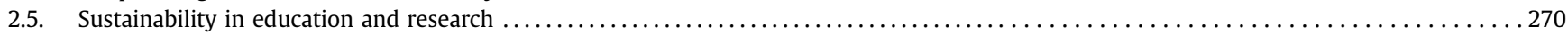

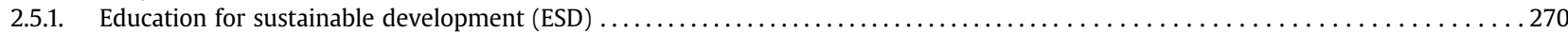

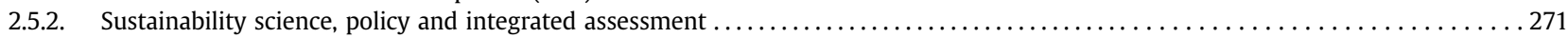

\footnotetext{
* Corresponding author.

E-mail addresses: alex.baker-shelley@maastrichtuniversity.nl (A. Baker-Shelley), a.vanzeijl@maastrichtuniversity.nl (A. van Zeijl-Rozema), p.martens@ maastrichtuniversity.nl (P. Martens).
} 


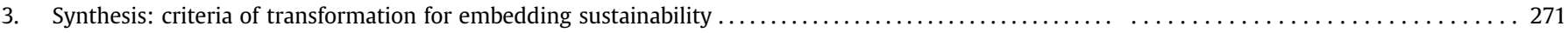

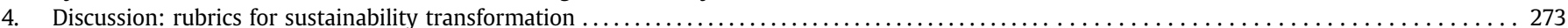

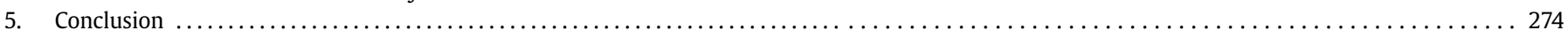

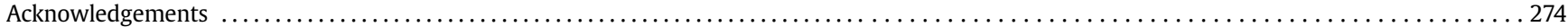

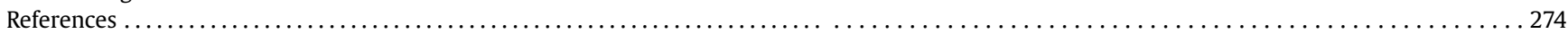

\begin{tabular}{|c|c|c|c|}
\hline \multicolumn{2}{|c|}{ Abbreviations } & \multirow{2}{*}{$\begin{array}{l}\text { HESI } \\
\text { IA } \\
\text { IIRC }\end{array}$} & \multirow{2}{*}{$\begin{array}{l}\text { Higher education sustainability initiative } \\
\text { Integrated assessment } \\
\text { International integrated reporting council }\end{array}$} \\
\hline AISHE & Audit instrument for sustainability in higher education & & \\
\hline BSP & Behavioural science and psychology & IGBP & International geosphere-biosphere programme \\
\hline CSR & Corporate social (\& environmental) responsibility & SDG & Sustainable Development Goals (of the United Nations) \\
\hline ESD & Education for sustainable development & SES & Socio-ecological systems \\
\hline ESG & Environmental social governance & SHE & Sustainability in higher education \\
\hline GAP & Global action programme & STARS & Sustainability tracking assessment and rating system \\
\hline GASU & Graphical Assessment Tool of Sustainability in & UNDP & United Nations development programme \\
\hline & Universities & UNDESD & United Nations decade of education for sustainable \\
\hline GRI & Global reporting initiative & & development \\
\hline HESD & Higher education for sustainable development & UNEP & United Nations environment programme \\
\hline HEI & Higher education institutions & UNGC & United Nations global compact \\
\hline
\end{tabular}

\section{Introduction}

In response to worsening crises of climate and capitalism, universities have a moral obligation to provide, through education and research, the societal transformation required of modes of production and consumption that are still based on economies that do not respect planetary boundaries (Rockström et al., 2009). Universities can play a profound and unprecedented role in a century in which society will be judged by its capacity for selftransformation in response to global sustainability crises, namely climate change, inequality and environmental refugees. Moreover, they have the capacity for innovation and societal engagement, acting as honest brokers: impartial mediators of knowledge across boundaries of science, policy and industry (Pielke, 2007). Yet, their potential to embed sustainability deeply into their own organisation remains largely untapped, (Lozano, 2011; Lozano et al., 2013b). Their incapability to set up structures to promote organisational learning, despite their being organisations of and for learning, is an intractable paradox (Stephens et al., 2008).

Much research has been undertaken regarding the 'what' of organisational transformation, corporate social responsibility (CSR), and sustainability reporting and accounting (Aras and Crowther, 2008, 2009; Clark and Master, 2012; Eccles et al., 2012; Lozano, 2006a; Zadek, 2006). Whereas, relatively little is known about how this transformation has to take place, vis-a-vis the operationalisation of sustainability into the core business of universities (Hoover and Harder, 2015). Greater focus should be put on the processes by which transformations towards sustainability occur (Stephens and Graham, 2010): pathways of societal transformations towards sustainability have been researched by Trencher et al. (2014a), and according to Yarime et al. (2012), this means taking into account the deep structure and inter-personality of a university, all its sub-systems, facilities, units and departments, including their interdependencies in a systemic and dynamic understanding. Relatedly, frameworks proposed aimed to overcome complexity and institutional inertia, such as the four-pronged strategy approach of Velazquez et al. (2006), and the portfolio approach towards integrating sustainability at organisations of Bertels et al. (2010a). Yet, many barriers and external drivers exist making the institutionalisation of sustainable development hard to achieve (Lozano, 2006a). The majority of universities lack descriptive, prescriptive or evaluative tools to operationalise their aspirations to become more socially and environmentally responsible. Therefore, this paper presents theories from diverse academic fields that could assist in the development of such tools; the objective being to integrate operational sustainability with approaches in research and educational agendas as well as community engagement - a 'whole-institutional' approach.

Whilst a "clear orientation on exactly what a sustainable university should be" is lacking (Velazquez et al., 2005), this paper takes the definition of a sustainable university as one that "addresses, involves, and promotes, on a regional or global level, the minimisation of negative environmental, economic, societal, and health effects generated in the use of ... resources in order to fulfil ... functions of teaching, research, outreach, partnership, and stewardship ... to help society ... transition to sustainable life-styles" Velazquez et al. (2006). This definition is based on the (economic, social and environmental) triple bottom line of sustainable development as defined in the Brundtland report (Elkington, 1999; World Commission on Environment and Development, 1987). One can argue that public universities in particular must aim for deeper sustainability because they have a moral obligation: they are recipients of public funds, have non-profit status, and are expected to serve the interests of society.

Section 1.1 offers a review of current policies in place to create sustainable universities. Section 1.2 introduces the research design. Thereafter, elements of organisational transformation towards sustainability at universities are presented in Section 2. In Section 3, a synthesised framework is developed of criteria that can describe and prescribe effective navigation of organisational transformation. In Section 4, the value, practicality and limitations of these rules of game are discussed, in terms of transformative capacity, leverage, and what the moral and ethical imperatives might be for universities.

\subsection{Current governance efforts to create sustainable universities}

In recent years, headway has been made with respect to the post 
Rio +20 agenda; for example the HESI commitments, and the Global Action Programme (GAP) on Education for Sustainable Development (ESD) play an enabling role in mobilising universities to ensuring a sustainable future (Simon and Haertle, 2014). Another encouraging trend is the rate of uptake of sustainability standards, social impact measures, partnerships for innovation with NGO's, business and civil society, and to a lesser extent communications strategies. Over the last decade this has done much to change the landscape of superficial and reactionary policy for sustainable development towards a deeper recognition to make it part of organisational DNA (Gray and Stites, 2013; Hespenheide and Koehler, 2012; KPMG, 2013). Moreover, this plays against the backdrop of a series of charters and declarations signed by global networks of universities to cement their commitment to the global transition toward a more sustainable society, such as: the Talloires Declaration (1990), the Copernicus Charter (1994), the Handvest Duurzaamheid HBO1 (1999), Agenda 21 (1992), and the most recent UN Decade for Education for Sustainable Development (2005-2014) (Boer, 2013; Lozano and Young, 2013; Sylvestre et al., 2013). These are mapped into trajectories of future sustainability scenarios of universities by Beynaghi et al. (2016).

Such scenarios are reflected in the emerging paradigm of institutional governance of co-creation for sustainability that goes beyond the traditional 'third-mission' (Trencher et al., 2014b) of a knowledge producing, technology-transferring university. Accordingly, recent studies have shown that the co-production and design of actionable knowledge, solutions and societal transformations for sustainability will grow, complemented by the launch of the Future Earth initiative, the renewal of the UNDP's Millennium Development Goals into Sustainable Development Goals (SDG's) and the growth of 'sustainability science' in the post-2015 agenda (Trencher et al., 2014a; Wiek et al., 2012).

\subsection{Research design: navigating pathways to sustainability at universities}

While the overall research question in this paper is what core elements are needed for transformation of universities towards sustainability, the following one is used to zoom into the subject matter: what does organisational transformation for sustainability entail with a university specifically?

The hypothesis was that common frameworks of analysis of sustainability pathways in organisations would benefit from tangible systemic rubrics for transformation. Hence, the research design follows an analytical review of the key areas of literature in order to better illustrate the nature of organisational transformations that embed sustainability, delineating core elements. Essentially, the rules of the game are unearthed in terms of working definitions, nuances and existing approaches. Then, building an analytical framework, niches are drawn from literature themes that can be used to hone in on the system under study.

This paper's analysis focuses on the complexity, causal symptomatic relationships, and the dynamic organisational nature of unsustainability. It works towards the modelling of the temporal and spatial elements of sustainable development pathways at universities. Specifically, it covers the first two steps: problem analysis (step one) from the systematic review of the literature in order to set goals (step two), which equate to themes in the identification of elements of organisational transformation for sustainability (Wiek and Lang, 2016). Moreover, this descriptiveanalytical approach (Spangenberg, 2011) can inform optimal solutions to problems of embedding sustainability into management, governance, strategy, culture and the 'core-business' of universities.

The literature was collated and organised by keyword terms using the primary academic research search engines and databases. Both academic and practitioner works were included. Because of the newness of sustainability science and policy as a body of integrated disciplines, no time limits were imposed. Literature themes were broken down into more precise concepts as articles were reviewed according to their core findings. These concepts were deductively organised into theoretical perspectives determining the analytical framework: the crux of this article.

\section{Theoretical perspectives for sustainability transformations}

A university's core-business is research, education, and societal engagement. It fundamentally operates within the 'world', composed of people that are organised into faculties, facilities and other social sub-systems. Systemically, this comprises of three entwined dimensions in a multi-layered view of governance and organisational transformation for sustainability: individuals (the micro-level), intra-organisational (meso-level), and extraorganisational: the system's interaction with the 'outside-world' (macro-level) at the local, municipal, regional, and global scales of societal engagement (Geels, 2002; Giddens, 1984; Turnpenny et al., 2008). Distinct theoretical perspectives are subsequently presented that paint a fuller picture of what transformation towards sustainability entails for universities, summarised in Table 1. Multiactor, multi-sector, multi-scalar dimensions predicate the findings from the literature review (see Table 2).

\subsection{Behavioural science and the psychology of sustainability}

The essential building block of organisations and institutions are individuals. They maintain systemic resilience through "function, self-organisation, learning and adaptation” (Clifton, 2010). Behavioural science and psychology allows an understanding of how individuals undergo (sustainability) transformation (Pfeffer, 2010). Individual behaviour affects a university's shift in awareness, whilst organisational culture and social norms act as determinants of individual behaviour (Ajzen, 1991; Lo et al., 2012).

Psychology and the behavioural sciences have increasingly recognised the need to tackle complex sustainability problems, whether socio-ecological, economic or cultural, in terms of the physical context of human wellbeing (Gifford, 2007; Oskamp,

Table 1

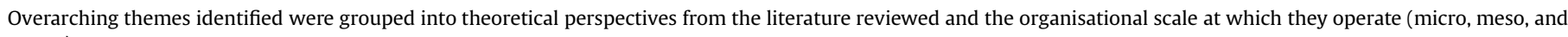
macro).

\begin{tabular}{|c|c|c|c|}
\hline $\begin{array}{l}\text { Theoretical Perspective for sustainability } \\
\text { transformation }\end{array}$ & $\begin{array}{l}\text { Micro-level: } \\
\text { Individual }\end{array}$ & $\begin{array}{l}\text { Meso-level: } \\
\text { Intra-organisational }\end{array}$ & $\begin{array}{l}\text { Macro-level: } \\
\text { Extra-organisational }\end{array}$ \\
\hline 2.1: Behavioural science and psychology & $\mathrm{X}$ & $\mathrm{X}$ & \\
\hline 2.2: Organisational change management & $\mathrm{X}$ & $\mathrm{X}$ & \\
\hline 2.3: Socio-ecological systems & & $\mathrm{X}$ & $\mathrm{X}$ \\
\hline 2.4: Corporate governance \& CSR & & $\mathrm{X}$ & $\mathrm{X}$ \\
\hline 2.5: Sustainability in education and research & $\mathrm{X}$ & $\mathrm{X}$ & $\mathrm{X}$ \\
\hline
\end{tabular}


2000; Schmuck and Vlek, 2003). There are relatively few studies from this field that specifically focus on individual transformation within universities for sustainable development. Conceptualising transformations as wicked problems, where the social complexity of the university itself proves an obstacle, then a solution presumably requires a psychological shift from denial to acceptance to recognise the nature of the problem and how to overcome it as an organisation (Conklin, 2005). Organisations should then have to consider that threats to the future inhabitability of the Earth by humanity, such as increasing atmospheric concentrations of greenhouse gases (GHG's), the exhaustion of fisheries and agricultural fertility, and ocean acidification, have been caused by overconsumption and overpopulation in aggregate human behaviour (Steinfeld et al., 2006). In terms of these threats therefore, a psychologist could investigate their effect on an individual's wellbeing and quality of life (Oskamp, 2000). Indeed the physical context of human behaviour is considered highly important (Pfeffer, 2010). It frames behavioural patterns, decisions, beliefs and how these can be determined by introverted motivations or extroverted ones to model an organisation (Bridges, 2000).

This leads to studies examining the role and importance of social norms in the function of organisational pro-environmental behaviour. Focus is recommended more on the role of the organisation's structure, sub-groups and culture, the latter of which is manifested in perceived support of superiors for environmental sustainability (Lo et al., 2012). According to Lo et al. (2012) there is a "lack of integrated analysis between individual and organisational determinants" illustrating a gap between these two behavioural levels. Furthermore, Schmuck and Vlek (2003) have framed environmental problems as 'common dilemmas', where individuals, by pursuing their own interests, freely shirk negative effects on their common physical and social environment. Other 'common dilemmas' include myopathy, having interests in the status-quo, technological optimism, nature-extractivist attitudes, and perceived lack of societal control over environmental sustainability problems (Schmuck and Vlek, 2003). This exemplifies social complexity in sustainability transformations: people who are confronted with the realities of environmental, social and economic challenges understandably often respond with negative, dysfunctional psychological attitudes.

The overview of BSP literature highlighted suggests theories presented in Table 2 - for how change-agents in universities can influence entrenched behaviour. Table 3 shows how they could strategise and enact this.

Table 2

Theories identified from the literature for their applicability to the challenge of individual-organisational sustainability transformation.

\begin{tabular}{|c|c|}
\hline Key theories for sustainability transformation & Description \\
\hline Ajzen's theory of planned behaviour (1991) & $\begin{array}{l}\text { Three determinants predict a person's intention to perform certain behaviour: personal } \\
\text { attitudes, social norms, and perceived behavioural control. By altering any of these three } \\
\text { selectively, a person's intention can change. This can predict and thus change behaviour; } \\
\text { a simplified relationship. }\end{array}$ \\
\hline The 'intention-behaviour' gap (Kollmuss and Agyeman, 2002) & $\begin{array}{l}\text { Although individuals might have the intentions to live in a 'sustainable' way, it is still } \\
\text { possible that they will not. }\end{array}$ \\
\hline $\begin{array}{l}\text { Determinants for individuals in pro-sustainability behaviour } \\
\text { (Adpated from Ajzen, 1991; Lo et al., 2012) }\end{array}$ & $\begin{array}{l}\text { - Whether or not an individual is convinced that sustainability is a good thing to do or } \\
\text { aim for. } \\
\text { - What the people who are important or influential in these individual's lives think, and } \\
\text { - Whether they have the capacity and control to change. }\end{array}$ \\
\hline Ethical organisational norms (Trevino et al., 2006) & $\begin{array}{l}\text { Ethical behaviour of individuals in organisations, influenced by rules and regulations, } \\
\text { organisational culture, and the moral judgement of individuals that determine more } \\
\text { explicit social norms and orientations. }\end{array}$ \\
\hline
\end{tabular}

Table 3

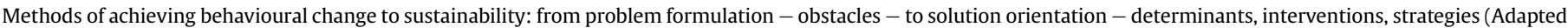
from Cameron, 2008; Gifford, 2007; Lo et al., 2012; Luthans and Avolio, 2009; Pfeffer, 2010; Schmuck and Vlek, 2003; Swim et al., 2011).

$\begin{array}{ll}\text { Integration of contributions relevant } & \text { Description } \\ \text { to achieving behavioural change } & \end{array}$

to achieving behavioural change

for sustainability

Obstacles to overcome

Possible Interventions

Determinants

Itemised action strategy
Socio-behavioural problem perception: a lack of collective problem awareness driven by personal interests Myopathy, interests in the status-quo, technological optimism, nature-extractivist attitudes, lack of societal control over environmental sustainability problems

Realities of climate change, environmental destruction, inequality, poverty drives negative, dysfunctional psychological attitudes: apathy, denial, anxiety, despondency and fear

Design, testing and evaluation of empirical studies and conceptual models about [sustainability] problems Appropriate physical facilities by providing the space for collaboration and technical innovation

Cooperation with policy-makers and other societal actors

Tailoring persuasive communication campaigns and decision environment design

Active engagement of middle management

Maintaining the psychological wellbeing of individuals increasing the chances of cautious optimism

Psychological capital and positive organisational behaviour: better self-awareness, balanced decision-making, transparency and ethical moral reasoning

(1) Provision of physical alternatives,

(2) Regulation and enforcement,

(3) Financial-economic stimulation,

(4) Provision of information and education,

(5) Social modelling and support,

(6) Organisational change,

(7) Changing values and morality. 
With respect to the linkages between social sustainability and organisational effectiveness, there has been "relative neglect of the human factor in sustainability research" (Pfeffer, 2010). For sustainability transformations at universities, this translates into a determinant for organisational effectiveness that depends on maintaining the psychological wellbeing of students and staff, since "as in the case of environmental sustainability, human sustainability pays off", increasing the chances of cautious optimism rather than pessimism (Gifford, 2007; Pfeffer, 2010).

Remaining applicable to the individuals populating universities, some studies point out how the resources - both social and psychological - of employees (staff and students) can overcome negative reactions such as cynicism, deviance and apathy associated with organisational change towards a desired end state (Cameron, 2008). The psychological state development of individuals can also be positively accelerated toward authentic leadership. This links 'psychological capital' and 'positive organisational behaviour', identifying how self-awareness, balanced decision-making, and ethical moral reasoning improve the human condition at the multiple levels (Luthans and Avolio, 2009).

Additionally, Gifford (2007) determines a spectrum of psychological states towards environmental problems, by concluding that "pessimism ... versus cautious optimism depends on how one weighs the growth, maturity, and future potential of environmental psychology against ... challenges and barriers". Therefore those who collectively work towards sustainability solutions might invisibly guide those pessimists, fatalists and individualists who seek self-interest "to promote an end which was no part of [their] intention" (see Table 3).

We finish therefore with the elements most relevant to sustainability transformations at universities. These have been translated into a diagnosis for sustainability transformation where it is indicated at which level they operate in Table 4.

\subsection{Organisational change management}

At the organisational level, processes of change are based on how individuals are managed and governed around common strategic goals, purposes and the core mission that defines their group; so, to seek an understanding of how universities understand the imperative for change processes, manage these effectively, and internalise "the changing nature of management, leadership and organisational change" is important (Howells et al., 2014). Especially so, since there has been little focus on organisational learning of universities - a paradox within higher education, as universities are organisations of learning, yet they struggle to set up structures to promote their own organisational learning (Stephens et al., 2008).
Every organisational member should represent its function, charter and goals, however these are fragmented "between the technical, managerial and institutional levels", driven by decentralisation of organisational core and periphery in relation to its vision, mission and ethics (Hannan and Freeman, 1984; Howells et al., 2014). A top-down 'command and control' paradigm is incompatible because it "reinforces blindness about the true nature of the problem" leading to systematic denial of the complex and illstructured dynamics of wicked problems (Conklin, 2005).

It is worthwhile investigating how universities actually 'do' this change, as evidence-based knowledge on "processes through which organisational change in public organisations come[s] about ha[s] received relatively little attention in academic research" (van der Voet, 2014). The six categories proposed by Kezar (2001) provide some insights, see box 1 . The evolutionary \& teleological

\section{Box 1}

Six categories of organisational development relevant for transformations toward sustainability at universities (Kezar, 2001).

Evolutionary: change is a response to external circumstances, situational variables, and the environment the organisation faces. Change is rational and linear.

Teleological: planned-change models; organisations are purposeful and adaptive and change occurs through change-agents and leadership, as well as being linear and rational.

Life-cycle: change is a natural part of human and organisational development, from infancy to maturity and decline.

Dialectical: political models; change as a result of clashing ideology or belief system, where conflict is inherent; processes of change are predominantly consisted of bargaining, consciousness-raising, persuasion, influence and power, and social movements.

Social Cognition: change is linked to mental cognitive processes of learning at an individual level, and driven by the individual's need or will to grow, learn and change their behaviour.

Cultural: change occurs naturally in response to alterations in the human environment, and the conditions under which the social systems operate.

Table 4

Diagnosis of sustainability transformation from behavioural science and psychological perspectives.

\begin{tabular}{|c|c|c|c|c|}
\hline No. & Behavioural science and the psychology of sustainability & Micro-level & Meso-level & Macro-level \\
\hline 1.1 & $\begin{array}{l}\text { Are negative reactions towards sustainability overcome by engendering } \\
\text { positive psychological/social resources \& wellbeing? }\end{array}$ & $\mathrm{X}$ & & \\
\hline 1.2 & $\begin{array}{l}\text { Are negative or positive reactions prevailing to sustainability with } \\
\text { regards to personal attitudes, social norms, and perceived behavioural } \\
\text { control? }\end{array}$ & $\mathrm{X}$ & & \\
\hline 1.3 & $\begin{array}{l}\text { What are the rules and regulations, organisational culture, and the } \\
\text { moral judgement of individuals towards sustainability? }\end{array}$ & $\mathrm{X}$ & $\mathrm{X}$ & \\
\hline 1.4 & $\begin{array}{l}\text { Are there appropriate physical facilities, tailored persuasive } \\
\text { communications, and active engagement of middle management? }\end{array}$ & & $\mathrm{X}$ & \\
\hline 1.5 & $\begin{array}{l}\text { Is positive organisational behaviour maintained in terms of better self- } \\
\text { awareness, balanced decision-making, transparency and ethical moral } \\
\text { reasoning? }\end{array}$ & $\mathrm{X}$ & $\mathrm{X}$ & \\
\hline 1.6 & $\begin{array}{l}\text { Is there cooperation between disciplines, faculties and with policy- } \\
\text { makers regarding sustainability problems and changing behaviour? }\end{array}$ & & $\mathrm{X}$ & $\mathrm{X}$ \\
\hline
\end{tabular}


change modes appear suitable elements of what is required for a deeper sustainability, whereas other modes are more descriptive of states of change:

The network for business sustainability (NBS) relatedly produced an assessment tool for embedding sustainability into organisational culture. Practices have two dimensions and four goals based on intent - fulfilment and innovation - and actuality formal and informal practices. The quadrant's contents are further divided into 'fostering commitment', 'clarifying expectations', 'instilling capacity for change', and 'building momentum for change' (Bertels et al., 2010b). Applying this to the university, it manages the triple bottom line, "delivering on a lofty triptych of environmental, social and economic goals" (Dixon and Clifford, 2007; Elkington, 1999) of its operations and decision-making, taking account of risks and opportunities. This approach arguably builds resilience, economic value, healthy ecosystems and strong communities; therefore such an organisation can innovate over the long term because of this practice's embeddedness (Bertels et al., 2010b).

Zadek (2006) distinguishes five organisational learning stages from a defensive to a civil stance (Fig. 1, y-axis) in a process "driven by contextual imperatives". Societal learning (x-axis) consists of the extent these imperatives "are driven in turn by changing expectations based on what society thinks is possible and desirable", in four stages according to the maturity of an environmental social governance (ESG) issue: from 'latent' to 'institutionalised' (Forstater et al., 2006; Zadek, 2006). At C, on organisation complies by responding to latent imperatives from issues on the societal agenda. At $B$, an organisation is still

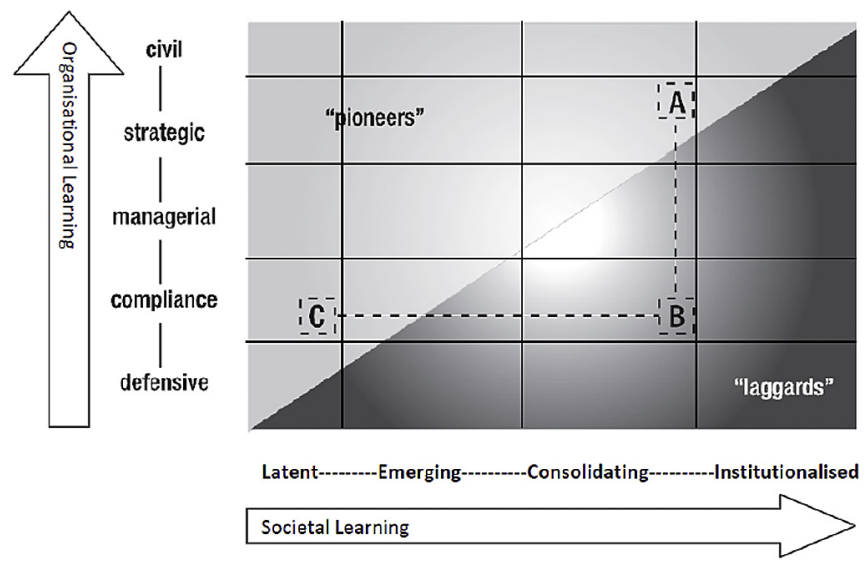

Fig. 1. A simplified model of the dynamic process of organisational and societal learning for sustainability. Adapted from (Shelley, 2013); Zadek (2006). compliant or managerially engaged, yet this is driven on a reactionary basis from institutionalised societal learning. Pioneers, at $A$, respond and anticipate to mature issues whilst adopting a civil engagement commensurate with their external task environment.

Incorporating the organisation-society learning dynamic element assists understanding how universities position themselves relative to societal expectations of their behaviour. Material ESG issues reflected in management practices can be dialogically communicated across the 'membrane' between intra and extraorganisational scales in order to account for sustainable development. This can seemingly occur in a reactionary manner to demands from societal pressures, as well as the managerial actions taken ex ante in order to anticipate and model future ESG risks and opportunities (Shelley, 2013). Notable synergy in higher education includes the fossil fuel divestment movement and the widening debate of the role of universities in the 21st century.

Whereas the Bridges Model of organisational development follows an evolutionary process, which describes the life-cycle of an organisation - progressing from the 'dream', to the 'venture', through 'getting organised', 'making it', 'becoming an institution', 'closing in' and 'death' (Bridges, 2000) - Roorda (2010) makes it clearer in the AISHE framework (an audit instrument for sustainability in higher education) how the learning process is applicable to universities. Subsequently, one of the four dichotomies used by Bridges, the distinction between introverted and extroverted organisations, is an important element. This describes organisations as on one hand having closed boundaries, reacting to external changes slowly, and on the other open boundaries being focussed on the outside world, reacting quickly to external changes (Bridges, 2000). In comparison with Zadek (2006), this is similar to the difference between laggards and pioneers (A \& B, Fig. 1). We postulate that universities transforming towards deep sustainability are pioneers or extroverted organisations.

Few studies in the organisational change literature have specifically linked the management of universities and institutional theory. According to Howells et al. (2014), a combination of drivers has caused the 'external task environment of universities' to change significantly; similarly to the evolutionary change model from Kezar (2001). Such drivers are listed as increasing globalisation of the educational system, international mobility of the staff and students, as well as the marketisation of higher education. They define institutional agency as "an organisational actor's ability to make an impact on the social order, changing the rules, relational ties or allocation of capital" and advocate four key themes as enablers of institutional change agency: vision, alignment, strategic collaboration and innovation (Howells et al., 2014).

Table 5

Criteria of sustainability transformation from the organisational change management perspective.

\begin{tabular}{|c|c|c|c|c|}
\hline No. & Organisational change management towards sustainability & Micro-level & Meso-level & Macro-level \\
\hline 2.1 & $\begin{array}{l}\text { Do both change-agents and leadership manage the triple bottom line of } \\
\text { environmental, social and economic responsibility? }\end{array}$ & $\mathrm{X}$ & $\mathrm{X}$ & \\
\hline 2.2 & $\begin{array}{l}\text { Do change-agents exhibit vision, alignment, strategic collaboration and } \\
\text { innovation to engage in partnership and collaborative governance with } \\
\text { wider society? }\end{array}$ & $\mathrm{X}$ & $\mathrm{X}$ & $\mathrm{X}$ \\
\hline 2.3 & $\begin{array}{l}\text { Is the response to the external task environment purposeful and } \\
\text { adaptive, resembling the evolutionary and teleological change-modes? }\end{array}$ & & $\mathrm{X}$ & $\mathrm{X}$ \\
\hline 2.4 & $\begin{array}{l}\text { Is the organisation learning from and anticipating maturing issues on } \\
\text { the societal agenda whilst adopting civil engagement commensurate } \\
\text { with its external task environment? }\end{array}$ & & & $\mathrm{X}$ \\
\hline 2.5 & $\begin{array}{l}\text { Is an extroverted organisational role adopted with open boundaries } \\
\text { focussed on the outside world, reacting quickly to changes in the } \\
\text { external environment? }\end{array}$ & & & $\mathrm{X}$ \\
\hline
\end{tabular}




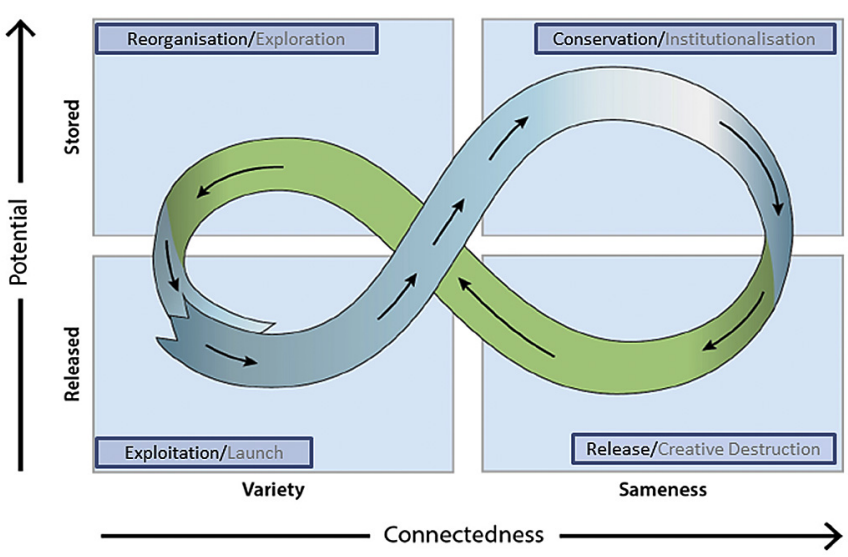

Fig. 2. The complex-adaptive cycle of an SES (Holling, 1986): illuminates the dynamics present in resilient social systems: innovation, adaptation and transformation (Folke et al., 2005; Gunderson and Holling, 2002). new configuration". "Ecosystem stewardship" uses a "fitness landscape" that links strategies, opportunity context and disruptive innovation for institutional entrepreneurs at key points in the cycle (Westley et al., 2013).

A university possesses the capacity for leadership, institutional entrepreneurialism, and socio-technical innovation toward an integrated governance and management of natural resources and ecosystem services (Westley et al., 2013). They can implement knowledge of complex-adaptive cycles for other organisations and societal actors.

Further to Holling's adaptive cycle, Scholz's (2011) humanenvironment systems postulates provide useful conceptual elements in analysing the step-change processes that iteratively determine the trajectory of transformational change. This ranges from the internal functioning of an organisation to how it interacts with the corpora institutions and ecosystems that make up the regional and global scale. The framework is meant to empower environmental literacy in science and society (Scholz, 2011).

Table 6

The seven proposed postulates of the Human-Environment Systems (HES) framework from Scholz (2011).

\begin{tabular}{|c|c|}
\hline Label & Postulate \\
\hline 1. Complementarity & Human and environment systems are complementary \\
\hline 2. Hierarchy & Human and environment systems both have hierarchical structures \\
\hline 3. Interference & $\begin{array}{l}\text { There are disruptive interactions among and within different levels of human and environmental systems, in particular between the } \\
\text { micro and macro levels }\end{array}$ \\
\hline 4. Feedback & There are different types of feedback loops within and between human and environmental systems \\
\hline 5. Decision & Human systems can be conceived as decision-makers who have drivers and who act to satisfy goals \\
\hline 6. Awareness & Human systems (social groups) have different types of environmental awareness \\
\hline 7. Environment-first & $\begin{array}{l}\text { The effective analysis of inextricably coupled human and environmental systems, as well as the planning for sustainable human- } \\
\text { environment interactions. }\end{array}$ \\
\hline
\end{tabular}

In conclusion, elements from organisational change management can help us identify firstly, what a sustainability transformation entails, and secondly how to diagnose one across three levels as presented in Table 5.

\subsection{Socio-ecological systems perspective}

The interwoven relationship between social, technical and biophysical systems applies to a university as an institution. It has the capacity for governance, co-creation and production of knowledge, innovation, adaptability, and the ability to solve societal and environmental challenges in interaction with the outside-world, and can thus be conceptualised as a complex system (Posner and Stuart, 2013). Theories and models from socio-ecological systems (SES) theory and coupled human-environmental relationships will help to frame a university's potential to transform itself to a viable alternative; this can lead to social resilience of individuals educated, and ecological resilience of the wider-world through its research. General systems theory is one lens for how phenomena of organisational transformations towards sustainability propagate (Gunderson and Holling, 2002; Wiek et al., 2012).

Universities are affected by dominant institutional arrangements, governance regimes, market-driven logic, and competitive organisational culture, shaping the emergence of socio-technical innovation and restricting appropriate and critical responses to complex challenges (Westley et al., 2011, 2013). Such drivers reinforce inertia of unsustainable patterns of consumption and production in complex adaptive systems at the 'conservation' phase of the adaptive cycle, presented in Fig. 2 (Holling, 1986). Navigating the release, and reorganisation phases, transformative agency enables "a transformation of the broader institutional system ... into a
Binder et al. (2013) classify the HES framework as analytical; to be applied "when a complex social-ecological issue is to be studied that involves a dynamic perspective on the social as well as on its interaction with the ecological system". For the purpose of analysing a university's transformation towards sustainability, aiming to improve wellbeing - corresponding to Table 6, P6 \& 7 in Scholz (2011) - and becoming aware of and reading the 'potential' of the external environment, are necessary steps. Furthermore, postulate three illustrates how the micro-level dynamics of a university affect its capacity to read its environmental and social potential to beneficially or detrimentally impact the macro-level 'outsideworld' (see Table 7).

Pursuing this further, system qualities might include institutional purposes and challenges where components - for example organisational branches (services, operations, communications) and stakeholder subcultures (students, staff, faculty) - interact in complex ways determining the behaviour of the institution: "an emergent quality that arises from interactions both within an institution and between the institution and the environmental and social contexts within which it operates" (Posner and Stuart, 2013). Relatedly, case-studies of two complex socio-ecological regional systems, using the framework of Panarchy (Gunderson and Holling, 2002), emphasise the importance of the role of university actors such as "students, educators, researchers, and academic practitioners" that lead by forging collaborative partnerships with local stakeholders; firstly, by building and maintaining resilient and sustainable SES and secondly, by encouraging innovation and transformability (Manring, 2014).

Elements identified from the socio-ecological systems perspective, which functions at the interface of the internal properties of the university as an SES and its external environment at 
the societal or regime level, have been translated into the below diagnosis of sustainability transformation, Table 7.
At an individual level, a case-study of a Dutch subsidiary of a USbased carpet-tile manufacturer, Interface, sheds light on current

Table 7

Rubrics for transformation at various scale levels from a socio-ecological systems perspective.

\begin{tabular}{|c|c|c|c|c|}
\hline No. & Transformational university as a socio-ecological system & Micro-level & Meso-level & Macro-level \\
\hline $3.1^{\mathrm{a}}$ & $\begin{array}{l}\text { a) Do institutional entrepreneurs enable bottom-up governance to challenge predominant sub- } \\
\text { optimal practices? } \\
\text { b) How do they link strategies, opportunity context and innovation in doing so? }\end{array}$ & $\mathrm{X}$ & $\mathrm{X}$ & \\
\hline $3.2^{\mathrm{a}}$ & $\begin{array}{l}\text { a) Does the organisation take responsibility that natural resources/ecosystems services are } \\
\text { managed and governed correctly by individuals and social groups practicing leadership, } \\
\text { entrepreneurship and sociotechnical innovation? } \\
\text { b) Is knowledge of how to do this transferred externally? }\end{array}$ & & $\mathrm{X}$ & \\
\hline 3.3 & Are the skills and competences for environmental literacy present? (Scholz, 2011) & & $\mathrm{X}$ & $\mathrm{X}$ \\
\hline 3.4 & $\begin{array}{l}\text { Do students, educators, and academics encourage innovation and transformability by forging multi- } \\
\text { scaler partnerships with actors at different geographical dimensions of society? }\end{array}$ & & $\mathrm{X}$ & $\mathrm{X}$ \\
\hline
\end{tabular}

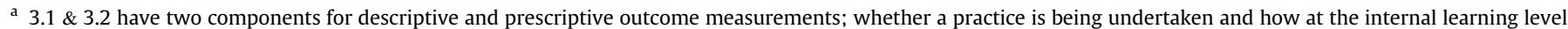
(3.1), and the external knowledge valorisation level (3.2).

\section{4. 'Corporate' governance for sustainability}

Whereas a socio-ecological system describes a university in terms of its interactions with the outside world, it arguably also has an extrinsic responsibility towards the world, expressed in corporate social responsibility (CSR), and moral agency as a response to obligations of justice driven by its social connections (Young, 2006). The transformational process towards sustainability can be guided by CSR principles, but might also result in a managerialism logic culture (Howells et al., 2014). Lessons from corporations that are learning and progressing to become more environmentally and socially responsible will be helpful for determining what makes a transformation towards a sustainable university.

Our future leaders, in public, private and civil society are educated by our universities. We therefore move to the perspective of corporate governance for sustainability; derived from corporate governance, corporate sustainability and CSR (Shelley, 2013). In viewing sustainable development as a sustained and balanced physical through-put, flowing from natural resources through the economy and back to natural sinks in a non-diminishing manner (Daly, 2006), social and environmental externalities of incorporated economic actors should be internalised so that no one human group has to bear the costs without compensation (Porter and Kramer, 2011). There is thus need for greater accountability of organisations beyond their traditionally introspective cultures and a revision of the liberal free market ideology (Abbott, 2012; Crouch, 2006; Warhurst, 2005; Zadek, 2006). A shift in ideology in recent decades for universities has seen homogenising managerial standards so swiftly become the norm, that they "are far from backed up by organisational arrangements and practical realities", illustrating the shift from the 'republic of scholars' model to the ‘stakeholder university’ model (Bleiklie and Kogan, 2007).

Although CSR is usually targeted at corporations, it is applicable to universities too. Universities must also manage the inflow and outflow of natural capital. Scherer et al. (2009) argue for a reconsideration of two assumptions based on the 20th century model of the firm in a liberalised democracy: firstly, that of "the sustained capacity and efficiency of the nation state system" and secondly, "the separation of public policy and private business". The boundaries between public and private have thus become increasingly blurred. Managerialist logics have superimposed over bureaucratic ones leading to a 'marketisation' of universities (Howells et al., 2014). CSR is moreover a policy tool in organisational change, applied to the university context in terms of tendering and external contracts to corporations. university models. Internal change-agents were identified as central to the learning process of embedding sustainability into corporate governance in articulating new ideas through sensemaking and emergent change. Top management were persuaded to provide resources due to the increased prevalence of sustainability in the societal learning agenda, and the agents' communications and action strategies as brokers, bricoleurs, and connectors, operationalised sustainability to the organisational context (van der Heijden et al., 2012).

Garriga and Melé (2004) classified forms of CSR in terms of instrumental theories: what an organisation does within the logic of its own interests to maximise value for stakeholders as its sole social responsibility; and political theories: realising its social power specific to its relationship with society as well as its responsibility in the political arena. The latter reflects the possible systemic effects over time from how the organisational community responds to calls for greater responsibility as a political economic actor in society (Söderbaum, 2008); accordingly, it accepts social duties and rights or participates in deigned social cooperation (Garriga and Melé, 2004). Is the organisation reactionary in framing their strategies and governance, in project acquisition, procurement or student recruitment? Or does it behave proactively as an engaged political economic actor, accepting its specific duties and cooperating to improve the community it serves (Garriga and Melé, 2004)? According to a Turkish case by Atakan and Eker (2007), a socially responsible university harnesses its assets and knowledge for addressing the needs and problems of the local community. This simultaneously requires a management of corporate identity that "is of great importance for organisational success" (Atakan and Eker, 2007).

Apart from individual and organisational issues, CSR monitoring plays a role as an organisation's means of communicating the extent of ESG issues, how important it considers them to be, and how they should be valued and disclosed externally according to key stakeholders (KPMG et al., 2013). It describes the threshold at which issues become sufficiently important that they should be reported, or beyond which the decisions of those accessing the organisation's statements are influenced (GRI, 2011). Thus, external reporting and internal monitoring processes of the sustainability performance of universities influences the decisions of stakeholders.

Another challenge is the diversity of sustainability assessment standards, with the likes of STARS for the North American institutional culture and AISHE for the European, amongst a plethora of others. Nonetheless, it is evident that the presence of any 
Table 8

Criteria for diagnosing a university's sustainability transformation through a Corporate Governance and CSR lens.

\begin{tabular}{|c|c|c|c|c|}
\hline No. & University governance for sustainability (CSR) & Micro-level & Meso-level & Macro-level \\
\hline 4.1 & $\begin{array}{l}\text { Do change-agents employ communications \& action strategies to persuade policy-makers and } \\
\text { management to allocate resources to raise sustainability on the learning agenda? }\end{array}$ & $\mathrm{X}$ & $\mathrm{X}$ & \\
\hline $4.2 \mathrm{a}$ & $\begin{array}{l}\text { Are ESG issues, material to the organisation and its stakeholders, measured, managed and } \\
\text { monitored internally by integrating sustainability strategy into governance, management and } \\
\text { administrative structures? }\end{array}$ & & $\mathrm{X}$ & \\
\hline $4.2 \mathrm{~b}$ & $\begin{array}{l}\text { After evaluation (4.2a) are ESG metrics disclosed to key external stakeholders, in substantiated and } \\
\text { understandable report of sustainability performance? }\end{array}$ & & & $\mathrm{X}$ \\
\hline 4.3 & $\begin{array}{l}\text { Is there a sustained and balanced physical through-put where social and environmental } \\
\text { externalities are internalised? }\end{array}$ & & $\mathrm{X}$ & $\mathrm{X}$ \\
\hline 4.4 & $\begin{array}{l}\text { Is responsibility adopted to be an engaged political actor, accepting social duties, participating in } \\
\text { deigned cooperation by partnering with external actors for collaborative governance and positive } \\
\text { societal impact? }\end{array}$ & & & $\mathrm{X}$ \\
\hline
\end{tabular}

monitoring system is an element of organisational transformation. This leads us to conclude with elements most suitable for questioning and diagnosing what sustainability transformations entail at universities in Table 8.

\subsection{Sustainability in education and research}

Interaction with the outside world also occurs through education and research. With respect to education, we focus on how it prepares students for the transformational sustainability challenges the world will face in response to what the IGBP calls the great acceleration: the collection of exponential trends of human development that shift our planetary influence to that of a geological force in its own right (Steffen et al., 2004; Stephens et al., 2008). With respect to its other core activity of research we focus on how sustainability transformation is encapsulated and reflected within this, notably by looking into sustainability research.

The grand challenges of sustainable development go wellbeyond the expertise, abilities, and resources of "any single player or organisation" (Kania and Kramer, 2011). The university could, therefore, play a role as a trans-sectoral actor and facilitator of transformational change in the 21st century; a tremendous opportunity to prepare the entire campus community to be better equipped to make decisions for a future that rapidly becomes more complex, dynamic and uncertain (Glasser et al., 2005; Yarime and Tanaka, 2012). Recent studies notably discern Higher Education for Sustainable Development (HESD) towards these transformational challenges: (Adomßent et al., 2014; Barth and Timm, 2011; Lozano et al., 2013a; Müller-Christ et al., 2014; Yuan and Zuo, 2013). Cross-sectoral partnerships, according to Trencher et al. (2014a), play a fertilising role that increase the chances of hurdling challenges in societal unsustainability encompassing the university and diverse societal actors. Several studies also reflect on the historical development of universities and the paradox of organisational learning in universities (Fallis, 2004; Sedlacek, 2013; Stephens et al., 2008; Trencher et al., 2014b). Sedlacek (2013) focusses on their actual and potential roles with respect to "fulfilling educational, research, governance and economic development ... [and] facilitative and mediating functions", after significant changes in these dimensions and the public sector as a whole in recent decades. Whereas, Fallis (2004), frames the challenge to universities culturally:

"The university is the primary institution of post-industrial society. It is one of the chief innovative forces of the society, one of the chief determinants of social opportunity and social stratification and a focus of intellectual and cultural life."

This builds the case for the moral imperative of the university in society, in light of how, instead, the university has been observed and modelled more as an actor for the global market rather than an advocate for civil society or the environment (Collini, 2012). Moves toward securing private funding for the continuation of research, education, other quotidian operations, and the incursion of commercial logic into public institutions and governance structures have been imposed, including "successive waves of misguided assessment procedures" (Ibid.2012). If this indicates predominant university governance models in a globalised world, then to assume tools from corporate social and environmental responsibility might counter this (section 2.4). An example of one such tool would be UNEP's 'Greening universities toolkit' that provides interdisciplinary resources for campus environmental management, stakeholder engagement and scope of responsibility (UN, 2012; UNEP, 2013).

Cortese (2003) elaborates on the critical role of universities in meeting international challenges, proposing the model of a university that has fully-integrated sustainability across four portfolios of research, education, operations and community. Velazquez et al. (2006) conceptualise a sustainable university as one that holistically or partly addresses, involves, and promotes, on a regional or global level, the minimisation of negative environmental, economic, societal, and health effects generated by the flow of resources through the system in order to fulfil its functions of "teaching, research, outreach and partnership, and stewardship"; thus improving the likelihood of achieving sustainable life-styles societally. Indeed, Posner and Stuart (2013) claim universities "behave as complex systems" making a clear link with SHE by proposing that "[SHE] is best seen an as emergent quality that arises from interactions both within an institution and between the institution and the environmental and social contexts within which it operates".

However, there is a gap between how the functions of a university are perceived by the outside world and by the individuals that constitute it; many different ideas exist about sustainable development. Accordingly, Lozano et al. (2015) found that efforts to implement sustainable development at 70 institutions were largely compartmentalised and recommended that university systems were composed of several inter-related elements. This indicates the disconnect between what the university teaches the youth with respect to future scenarios of sustainability challenges, what it envisages its societal and governance purposes are, and finally what it is actually capable of doing (M'Gonigle and Starke, 2006). This perspective thus now breaks into two further dimensions: Education for Sustainable Development (ESD), and Sustainability Science, Policy and Integrated Assessment (IA).

\subsubsection{Education for sustainable development (ESD)}

UNEP has defined education for sustainable development as "actually just a higher stage of development within the very 
powerful and inclusive realm of environmental education" (UNEP, 2013). Whereas others have taken a contextual stance: "a learning process ... based on the ideals and principles that underlie sustainability ... is concerned with all levels and types of education" (Karatzoglou, 2013).

Daly (2006) sees sustainability "as a way of asserting the value of longevity and intergenerational justice, while recognising morality and finitude", emphasising that the youth of today have a stake in the future state of the world that is left to them. Considering globalisation, climate change, biodiversity loss, social inequality, and a void of trans-boundary governance on a global-level, the potential universities possess to prepare the youth for such a future is inimitable. This mission embodies principles of intergenerational justice and socio-ecological equilibrium.

UNEP and UNDP have both spearheaded measures to form strategic partnerships with young people, governments and businesses in order to deliver the vision that the UNDESD posed (UNEP, 2013). Their guidelines illustrate how different methods and strategies are used. Other examples include the UNGC's guide for implementing the global sustainability standard's principles and communicating on progress made (UN, 2012), and the recent GAP (UNESCO, 2014). Standards and guidelines such as these highlight the role ESD plays in a university's transformation as a complex system for sustainable development (SD).

The transformation that has taken place in ESD was systematically analysed by Beynaghi et al. (2016) in order to extrapolate future scenarios for universities beyond UNDESD. The paradigmatic, functional and goal related shifts are clearly presented in a graduated advancement of 'the nexus between $\mathrm{HE}$ and SD', from a new attitude in HE toward SD, to sustainability in HE, to HE for SD. The significance and logic of specifically university implementation of ESD is supported because of their expanded core business: to imbue graduates with the innovation, adaptability, and knowledge to solve societal and environmental challenges and make decisions for an increasingly complex, dynamic and uncertain future (Glasser et al., 2005; Posner and Stuart, 2013; Yarime and Tanaka, 2012). Relatedly, Wiek et al. (2011) presciently synthesised sustainability research and problem-solving competencies to prepare graduates for this future. They focus on five key competences: systemsthinking, anticipatory, normative, and strategic with the crosscutting interpersonal competence in sustainability linked to basic competences, see Fig. 3.

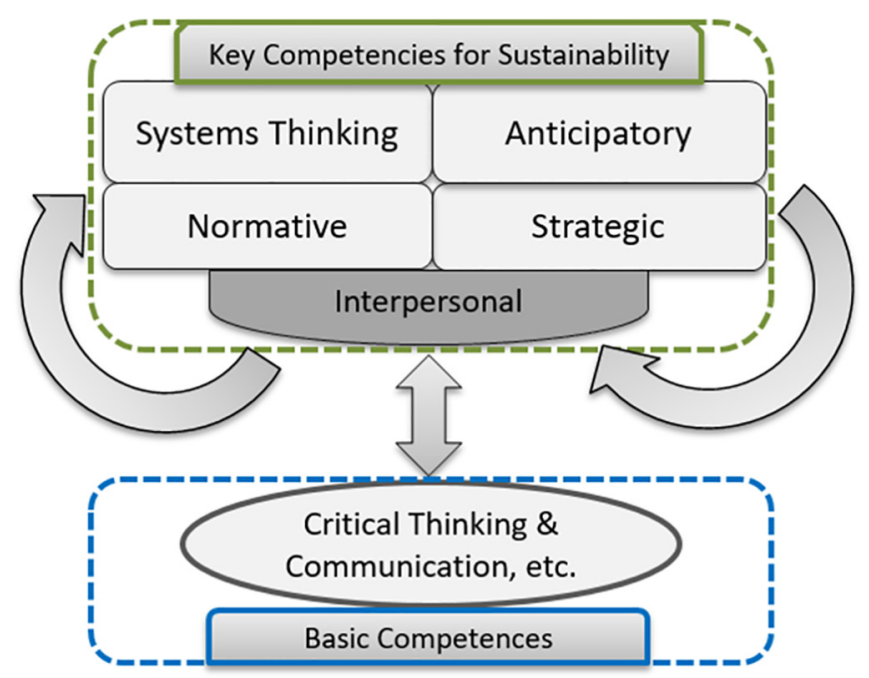

Fig. 3. Key competences in sustainability intended for graduates (Adapted from Wiek et al., 2011).

\subsubsection{Sustainability science, policy and integrated assessment}

Research for sustainable development, also known as Sustainability Science, yields answers about transformative processes. It implies that complex concepts require equally complex framings, bringing temporal and spatial dimensions into account as well as the stakeholders involved. It refers to a societal process of change towards a desired quality-of-life, now and in the future, and pluralistic approaches that engage diverse actors at multiple levels, creating an integrated vision built on shared concern towards a shared solution, resolving trade-offs iteratively (Zeijl-Rozema van et al., 2008). To attempt to capture the fundamental paradigm, function, and goal-related shifts that have taken place from sustainability science, a variety of lenses have been posited: postnormal science, mode- 2 science, action research, and IA amongst others (Funtowicz and Ravetz, 1993; Rotmans, 2006; Waterman et al., 2001). This indicates a paradigm shift of scientific method from a descriptive-analytical mode- 1 type knowledge production to a transformative, solutions-orientated and transdisciplinary mode-2 type (Spangenberg, 2011).

Leading on from this, Lang et al. (2012) make the distinction between the paradigms (post normal, mode 2, triple helix) and their corresponding research practices (transdisciplinary research, community based, interactive, or participatory approaches). Action research is one of these research practices for 'doing' sustainability science "as a problem and solution-oriented field". This method is hence valuable for novel approaches to sustainability transformation via "collaborations among scientists from different disciplines and non-academic stakeholders from business, government, and the civil society in order to address sustainability challenges and develop solution options." This responds to the call for participatory procedures involving scientists, stakeholders, advocates, active citizens, and knowledge implementers (Kates et al., 2001).

IA correspondingly pools such tools for transformative purposes, leveraging research at universities to achieve practicable societal outcomes from sustainability science. A scientific framework of the selection of multiple tools in an IA is presented in four generic phases by de Ridder et al. (2007), summing up solution development to complex challenges regarding research and sustainability science:

1. Problem analysis: understand and frame the problem in the light of various perspectives.

2. Finding options: an exploration of possible scenarios that elucidate visions of pathways to sustainable futures.

3. Analysis: the characterisation of plausible scenarios and policy interventions in order to select options and solutions for intervention.

4. Follow-up: the reflection on the entire process in order to deduce and integrate lessons that improve future assessment processes from the evaluation of the results of the analytical phase.

The interdisciplinary and post-normal nature of sustainability science is, in conclusion, appropriate for enhancing the role of universities; implementing the GAP for ESD (UNESCO, 2014), reflecting on the UNDESD (2004-2015), now applying United Nations SDG's to equip communities for a complex and uncertain future. Table 9 presents elements derived from educational and research perspectives for what sustainability transformation entails across universities' core functions.

\section{Synthesis: criteria of transformation for embedding sustainability}

This section synthesises the elements from the systematic 
Table 9

Criteria for diagnosing sustainability transformation at various scale levels from educational and research perspective.

\begin{tabular}{|c|c|c|c|c|}
\hline No. & Diagnosis of sustainability transformation from educational and research perspectives & Micro-level & Meso-level & Macro-level \\
\hline 5.1 & $\begin{array}{l}\text { Are students and staff educated or trained in the five sustainability competences for transformation: } \\
\text { systems thinking, anticipatory, normative, strategic, and interpersonal? }\end{array}$ & $\mathrm{X}$ & & \\
\hline 5.2 & $\begin{array}{l}\text { Are principles of intergenerational justice \& socio-ecological equilibrium embodied in practice of } \\
\text { research \& education? }\end{array}$ & $\mathrm{X}$ & $\mathrm{X}$ & \\
\hline $5.3 a$ & $\begin{array}{l}\text { Are integrated sustainability practices identifiable across all portfolios of research, education, } \\
\text { operations, governance and communications? }\end{array}$ & & $\mathrm{X}$ & \\
\hline 5.4 & $\begin{array}{l}\text { Ideal-typical transdisciplinary research process followed: (Phase 1) collaboratively framing the } \\
\text { problem; (Phase 2) co-production of solution-orientated transferrable knowledge, (Phase } 3 \text { )(re-) } \\
\text { integration and application of such co-produced knowledge in scientific and societal practice (Lang } \\
\text { et al., 2012). }\end{array}$ & & $\mathrm{X}$ & $\mathrm{x}$ \\
\hline 5.5 & $\begin{array}{l}\text { Are interdisciplinary resources for campus environmental management, internal stakeholder } \\
\text { engagement and scope of responsibility utilised? }\end{array}$ & & $\mathrm{X}$ & $\mathrm{X}$ \\
\hline 5.6 & $\begin{array}{l}\text { Is the minimisation of negative environmental, economic, societal, and health effects generated by } \\
\text { the flow of resources holistically driven? }\end{array}$ & & $\mathrm{X}$ & $\mathrm{X}$ \\
\hline $5.7 \mathrm{a}$ & Does substantive content of research and education functions target generation of societal impact? & $\mathrm{X}$ & $\mathrm{X}$ & \\
\hline $5.7 \mathrm{~b}$ & $\begin{array}{l}\text { Is a significant level of public consciousness identifiable that the research \& education the university } \\
\text { does has positive societal impact? }\end{array}$ & & $\mathrm{X}$ & $\mathrm{X}$ \\
\hline 5.8 & $\begin{array}{l}\text { Are global, regional \& national sustainability standards, assessment frameworks \& principles } \\
\text { relevant to university-contexts (UNGC, STARS, GRI, IIRC, AISHE) implemented and is progress and } \\
\text { performance communicated? }\end{array}$ & & $\mathrm{X}$ & $\mathrm{X}$ \\
\hline $5.3 b$ & $\begin{array}{l}\text { In fulfilling core portfolio functions of education, research, communications, operations and } \\
\text { governance, university improves likelihood of generating sustainable life-styles for societal actors } \\
\text { via its community's actions. }\end{array}$ & & & $\mathrm{X}$ \\
\hline
\end{tabular}

review of five theoretical perspectives to help identify levers for action for universities' transformation towards sustainability.

In order to enable future projects to increase traction and decrease inertia, criteria developed from theoretical elements translated into a framework that could later be used for practical evaluation and diagnosis. Results of this process are presented in

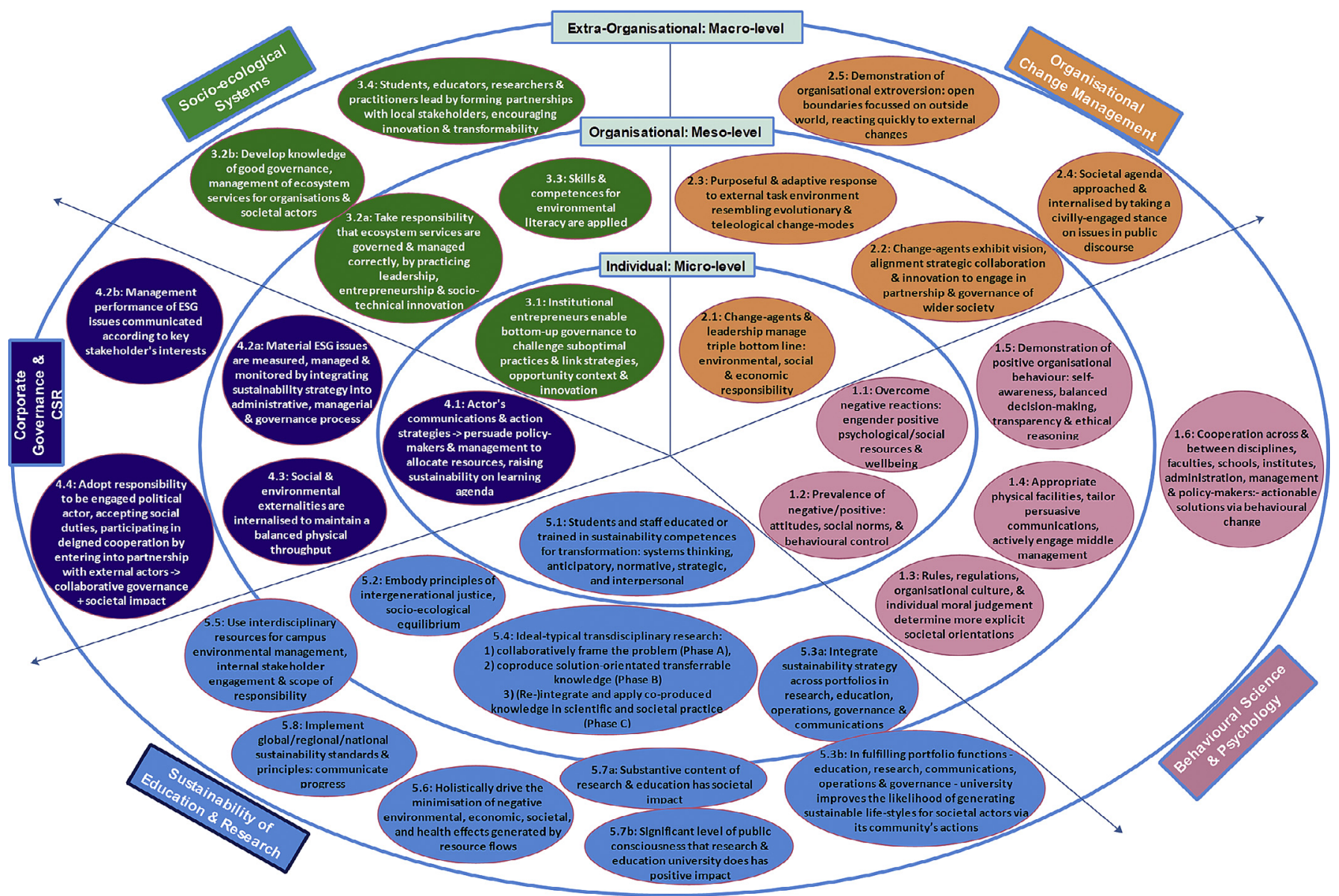

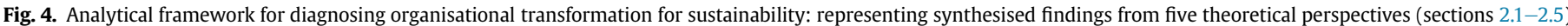

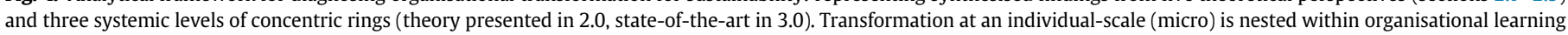
and 'self'-reflection (meso), in turn nested in larger societal transformation (macro). 
Fig. 4 at:

1) Individual - micro-level inwards

2) Intra-organisational - meso-level inwards

3) Extra-organisational - macro-level inwards

These traverse the aforementioned five theoretical perspectives, additionally derived from these dimensions:

1) Multiple actors: individuals or stakeholders constituting universities: the micro-scale.

2) Multiple sectors: disciplines and organisational types: the meso-scale.

3) Multiple scales: between institutions, at the national or policymaking level: the macro-scale.

This model is bolstered by insights gained from the review of IA, influenced by the dynamic multi-level framework of transitions studies for socio-technical change (Geels, 2002), and integrated policy assessment. This pinpoints institutional capacities and constraints respectively to the scales of individual agency, institutional structure and national and international policy landscapes (Turnpenny et al., 2008). Examples of the latter are policies that restrict or enable universities' ability to assess and independently choose their contractual arrangements through tendering. Holistically, this means a view of the university that extends to "multiple and complex causal relationships between agency and structure, [concerning] issues driving and affected by social change in different ways ... contexts ... and at different levels from macro to micro" (Turnpenny et al., 2008). This interconnected scalar approach finds credence in how the behaviour of individuals and the organisation itself is determined through social structure in structuration theory, which sees no split between the individual and the social because of their reflexive relationship (Giddens, 1984). This bears significant implications for learning and knowledge creation (Stacey, 2001), especially as a prerequisite for organisational behavioural change nested in larger societal transformation.

This research conceptualises an organisational transformation of a university towards non-absolute deeper sustainability, punctuating the dynamic equilibrium of the system. This entails the means, methods and processes by which the subject organisation functions as adaptive management to pursue societal wellbeing and resilience of an SES, allowing 'equifinality': a choice in the manner of navigating toward a shared end-goal. This concerns its environmental relationship with its surroundings, evolving along a developmental growth pattern. In terms of the 'throughput' of an organisation's metabolism, it tends to a steady state corresponding to minimum entropy production sustaining the system conditions. So, organisational transformation for sustainability consists evolving towards a state of higher resilience in bursts of rapid, discontinuous change (Brauckmann, 2000; Daly, 2006; Romanelli and Tushman, 1994; Spangenberg, 2011; Vos, 2007; Voß and Kemp, 2006).

\section{Discussion: rubrics for sustainability transformation}

In this section the value, applicability, and limitations of the analytical framework are discussed. No single perspective provides the full overview of elements entailing organisational transformation for sustainability, that were synthesised and structured according to the scale level at which they operate (Table 1). Three concentric circles of criteria at the micro, meso and macro scales, provide a holistic picture of what this transformation entails, acting as an important entry point. A sustainability transformation appears to manifest itself through the lens of each of these perspectives. In this sense, analysing through the use of just one perspective at three levels is not enough. To substantively gauge what sustainability transformation entails and where on the pathway an organisation lies, they should be used in holistic complementarity.

Many of the elements identified, once streamlined, operate as criteria that describe the system under analysis. When tested in the field at higher granularity, the criteria could be validated for prescriptive and evaluative purposes, subsequently operating as conditional rubrics composed of synthesised elements from each of the theoretical perspectives, and multi-scalar, multi-dimensional nature of organisational transformation. In the interim, a tool is being developed according to field-tested criteria, from synthesised analytical elements, preceded by early iteration action research at Maastricht University. Practically, it might help evaluate where on their journey universities are: how to navigate transformation in a logical sequence or action strategy for decision-makers.

Two modus operandi arose to gauge organisational transformation for sustainability:

1 Descriptive: describes the current state of affairs, observations useful for analysing the current situation of a university: a snapshot of systemic sustainability performance. I.e. what is the state of things?

2 Prescriptive: Normative recommendations for becoming a more sustainable university, involving the possible 'prescriptions' of different pathways the organisation can take along its transformation: i.e. what should be done and how?

An organisation's transformation towards sustainability can also be viewed with:

- An intrinsic perspective: using criteria - e.g. from behavioural science - that function from the intrinsic logic of an organisation for "adaptation, innovation and evolution" (Crow and Dabars, 2015, p.8)

- An extrinsic perspective: how the university is envisaged in alternative pathways of transformation - e.g. Scholz's (2011) postulates of reading the systemic background, or Zadek's (2006) model of the dynamic process of organisational and societal learning.

These are practically relevant for navigating pathways of transformation for sustainability at universities. Similarly, Beynaghi et al. (2016) delineate project scenarios as policy tools for internal and external decision-makers in their analysis of the post Rio +20 UNDESD agenda.

To show how the tool could be used, a university might be, under a descriptive diagnosis, implementing sustainability standards for reporting and communicating their progress (cr.5.8). However, after evaluating activities, it is found that it needs to perform behavioural interventions using pro-sustainability determinants of staff and student intentions (cr.1.2), because there is a behaviour-intentions gap. It might then need to provide physical facilities, tailor communications, and actively engage middle management to remedy the gap (cr.1.4).

Some overlap exists between perspectives and levels, and more could be added. The distinction between the descriptive and prescriptive dimensions, boundaries between scales, perspectives and organisational limits will remain difficult until tested in the field. Other similar tools may have developed for visualizing or prompting university transformations towards sustainability in the literature: for example GASU, aimed to help universities track sustainability trajectories, making recommendations for where a 
university should leverage its system to become more aligned with the UNDESD (Lozano, 2006b). Although, before the conceptual review was made, it was not clear which institutional models most harboured transformation, current beta-testing of the diagnosis tool on targeted cases on different continents, seems to highlight public research universities. Preliminary results show that it is valid, stakeholders see it as useful and it provides tangible insights into the current state of affairs as well as potential room for improvement. Moral arguments in this paper and the practical implication of its outcome - a prototype diagnosis tool - may apply more to young public research universities, as their explicit missions are founded not just on knowledge enterprise, but on public good and societal impact (Morphew and Hartley, 2006), whilst also being "uniquely positioned to assume an obligation to construe their purposes" in these contexts (Crow and Dabars, 2015, p. 25). Future research might therefore focus on institutional differentiation and evolution of public research universities that have implemented a major departure from traditional design.

The tool synthesises state-of-the-art theories that beg testing in the field, commensurate with the pragmatic idealism required to concretise the ideal of sustainability through productive inquiry ((Bozeman, 2007) in (Crow and Dabars, 2015, p.222)). Adopting holism for 'thick' or more profound sustainability (Vos, 2007) the nature of complex institutions are rendered more salient as they are dismantled into analytical units (such as faculties, facilities, student organisations, committees and boards) to examine the underlying social relationships and mechanisms ((Wallerstein, 1974) in (Moses and Knutsen, 2012)).

The findings could also align with the SDG's: to reduce inequality and unemployment, mitigate deleterious air, water and soil pollution, enable access to higher education, graduating students to better meet sustainability problems with measures for increasing resilience, good governance and effective management of SES. How a university recognises its sustainability problems, learns, adapts and embeds it into its institutional governance, can also be framed as a process of awakening. In this light, rubrics of organisational transformation help standardise comparison of ESG performance in similar cultural and regional contexts, where students, academics, researchers and practitioners co-create knowledge in a republic of stakeholders. This seems pertinent for driving existing or potentially new forms of internal and external policy to influence university behaviour along different pathways and manifestations of sustainability (Beynaghi et al., 2016), engendering a broad palate of outcomes from participatory action research on transformations towards sustainability.

\section{Conclusion}

The potential of organisational transformation for sustainability at a university is determined by extroverted engagement with a prioritised array of ESG issues, performed in collaborative governance with actors from across different sectors (private, public, and civil-society), following a dynamic process of organisational learning in evolutionary and teleological modes of change. This could benefit the psychological wellbeing of those who walk its corridors, drawing on integrated and systemic thinking to involve a diverse network of social actors across multiple disciplines and scales. A university is defined by its 'cellular' individual behaviour as well as that of the organisation: how it accounts and measures its internal processes and its external interaction and responsibility to the wider world.

This conceptual review and synthesis posits a sustainability ethic for universities: a preservation of the rights of future generations to meet their own needs with the right use of knowledge, transdisciplinary research and technology, driven by a post-neo- liberal 21st century education. They must play a role in transforming their surrounding communities and society if they too are to attain a greater depth of sustainability; applying knowledge of structural transformations in and of their surrounding societies. Being nested as a sub-system in society, their sustainability is also dependent on that of their social environment. In response to worsening crises of climate and capitalism alike they have a moral obligation to provide, through education and research, the societal transformation required of current modes of production and consumption that are still based on economies that ignore ecological limits.

The way public institutions are managed has been changing unprecedentedly. It is unclear what scenarios will manifest themselves; 'the wheel is still in spin' and paradigms change in and of science as a result of external perturbation and crisis (Kuhn, 1996). Ergo, predominant management and governance structures of universities, and how these differ from the models required to meet local, regional and global sustainability challenges progressing through the rest of this century, must remain a core transdisciplinary research priority, both within and beyond the halls of academia.

\section{Acknowledgements}

The authors thank the four anonymous reviewers who helped tie off loose ends in the complex weave of the article and provided invaluable feedback and validation. They also wholeheartedly thank their colleagues at ICIS, who helped them to streamline, critique and structure the research process; in particular, Laura Kürth for her incisive proof-reading and brainstorming, and Joop de Kraker for his fielding tip. The first author is furthermore very grateful for the opportunity to research in action at Maastricht University, working alongside its Green Office. Many of the ideas that rooted the problem definition and conceptualisation required for this work came from meetings and interviews with all Green Office staff; Jüdith Enders and Ricardo Leclaire especially.

\section{References}

Abbott, K.W., 2012. Engaging the public and the private in global sustainability governance. Int. Aff. 88, 543-564.

Adomßent, M., Fischer, D., Godemann, J., Herzig, C., Otte, I., Rieckmann, M., Timm, J., 2014. Emerging areas in research on higher education for sustainable development - management education, sustainable consumption and perspectives from central and eastern Europe. J. Clean. Prod. 62, 1-7.

Ajzen, I., 1991. The theory of planned behaviour. Organ. Behav. Hum. Decis. Process. $50,179-211$.

Aras, G., Crowther, D., 2008. Governance and Sustainability: an investigation into the relationship between corporate governance and corporate sustainability. Manag. Decis. 46, 433-448.

Aras, G., Crowther, D., 2009. Making sustainable development sustainable. Manag. Decis, 47, 975-988.

Atakan, M.G.S., Eker, T., 2007. Corporate identity of a socially responsible university - a case from the Turkish higher education sector. J. Bus. Ethics 76, 55-68.

Barth, M., Timm, J., 2011. Higher education for sustainable development: students perspectives on an innovative approach to educational change. J. Soc. Sci. 7, 13-23.

Bertels, S., Papania, L., Papania, D., 2010a. Embedding sustainability in organizational culture: a how-to guide for executives. Netw. Bus. Sustain. 20.

Bertels, S., Papania, L., Papania, D., 2010b. Embedding sustainability in organizational culture: a systematic review of the body of knowledge. Netw. Bus. Sustain. 74.

Beynaghi, A., Trencher, G., Moztarzadeh, F., Mozafari, M., Maknoon, R., Leal Filho, W. 2016. Future sustainability scenarios for universities: moving beyond the united nations decade of education for sustainable development. J. Clean. Prod. 112 (4) 3464-3478.

Binder, C.R., Hinkel, J., Bots, P.W., Pahl-Wostl, C., 2013. Comparison of frameworks for analyzing social-ecological systems. Ecol. Soc. 18 (26).

Bleiklie, I., Kogan, M., 2007. Organization and governance of universities. High. Educ. Policy 20, 477-493.

Boer, P., 2013. Assessing sustainability and social responsibility in higher education assessment frameworks explained. In: Caeiro, S., Filho, W.L., Jabbour, C.J.C., Azeiteiro, U.M. (Eds.), Sustainability Assessment Tools in Higher Education 
Institutions. Springer, pp. 121-137.

Bozeman, B., 2007. Public Values and Public Interest: Counterbalancing Economic Individualism. Georgetown University Press.

Brauckmann, S., 2000. The organism and the open system. Ann. N. Y. Acad. Sci. 901, $291-300$.

Bridges, W., 2000. The Character of Organizations: Using Personality Type in Organization Development. Nicholas Brealey Publishing.

Cameron, K.S., 2008. Paradox in positive organizational change. J. Appl. Behav. Sci. $44,7-24$.

Clark, L., Master, D., 2012. In: Boerner, H., Coppola, L.D. (Eds.), Corporate ESG/Sustainability/Responsibility Reporting: Does it Matter?. Governance and Accountability Institute Inc., New York, p. 2012.

Clifton, D., 2010. Progressing a sustainable world: a socio-ecological resilience perspective. J. Sustain. Dev. 3.

Collini, S., 2012. What Are Universities for? Penguin books Ltd, London, United Kingdom.

Conklin, J., 2005. Wicked Problems and Social Complexity, Dialogue Mapping: Building Shared Understanding of Wicked Problems. John Wiley \& Sons, pp. $1-20$.

Cortese, A.D., 2003. The critical role of higher education in creating a sustainable future. Plan. High. Educ. 15-22.

Crouch, C., 2006. Modelling the firm in its market and organisational environment: methodologies for studying corporate social responsibility. Organ. Stud. 27, 1533.

Crow, M.M., Dabars, W.D., 2015. Designing the New American University. John Hopkins University Press.

Daly, H.E., 2006. Sustainable development - definitions, principles, policies. In: Keiner, M. (Ed.), The Future of Sustainability. Springer, The Netherlands, pp. 39-53.

de Ridder, W., Turnpenny, J., Nilsson, M., von Raggamby, A., 2007. A framework for tool selection and use in integrated assessment for sustainable development. J. Environ. Assess. Policy Manag. 9, 423-441.

Dixon, S.E.A., Clifford, A., 2007. Ecopreneurship - a new approach to managing the triple bottom line. J. Organ. Change Manag. 20, 326-345.

Eccles, R.G., Krzus, M., Rogers, J., Serafeim, G., 2012. The Need for Sector-specific Materiality and Sustainability Reporting Standards, vol. 24. Morgan Stanley, pp. 65-71.

Elkington, J., 1999. Cannibals with Forks: the Triple Bottom Line of 21st Century Business. Capstone Publishing Limited, Oxford.

Fallis, G., 2004. The Mission of the University. Department of Economics and Division of Social Science, York University, Toronto Canada.

Folke, C., Hahn, T., Olsson, P., Norberg, J., 2005. Adaptive governance of socialecological systems. Annu. Rev. Environ. Resour. 30, 441-473.

Forstater, M., Zadek, S., Evans, D., Knight, A., Sillanpää, M., Tuppen, C., Warris, A.-M., 2006. The Materiality Report: Aligning Strategy, Performance and Reporting. AccountAbility, BT Group Plc and LRQA.

Funtowicz, O.S., Ravetz, R.J., 1993. Science for the post-normal age. Futures $739-755$.

Garriga, E., Melé, D.n., 2004. Coroporate social responsibility theories: mapping the territory. J. Bus. Ethics 53, 51-71.

Geels, F.W., 2002. Technological transitions as evolutionary reconfiguration processes: a multi-level perspective and a case-study. Res. Policy 31, 1257-1274.

Giddens, A., 1984. The Constitution of Society: Outline of the Theory of Structuration. Polity Press, Oxford; Cambridge.

Gifford, R., 2007. Environmental psychology and sustainable development: expansion, maturation, and challenges. Soc. Psychol. Study Soc. Issues 63, 199-212.

Glasser, H., Calder, W., Fadeeva, Z., 2005. Definition: Research in Higher Education for Sustainability. Halifax, Nova Scotia.

Gray, B., Stites, J.P., 2013. Sustainability through Partnerships: Capitalizing on Collaboration. Network for Business Sustainbility, p. 109.

GRI, 2011. Sustainability Reporting Guidelines: Version 3.1. The Global Reporting Initiative, Amsterdam.

Gunderson, L., Holling, C.S., 2002. Panarchy: Understanding Transformations in Human and Natural Systems. Island Press, Washington DC.

Hannan, M.T., Freeman, J., 1984. Structural inertia and organizational change. Am. Sociol. Assoc. 49, 149-164.

Hespenheide, E., Koehler, D.A., 2012. Disclosure of Long-term Business Value: what Matters? Deloitte Development LLP, p. 18.

Holling, C.S., 1986. The resilience of terrestrial ecosystems: local surprise and global change. In: Clark, W.C., Munn, R.E. (Eds.), Sustainable Development of the Biosphere. Cambridge University Press, Cambridge, U.K, pp. 292-317.

Hoover, E., Harder, M.K., 2015. What lies beneath the surface? The hidden complexities of organizational change for sustainability in higher education. J. Clean. Prod. 106, 175-188.

Howells, J.R.L., Karata -Ozkan, M., Yavuz, C., Atiq, M., 2014. University management and organisational change: a dynamic institutional perspective. Camb. J. Regions, Econ. Soc. 7, 251-270.

Kania, J., Kramer, M.R., 2011. Collective impact. In: Stanford Social Innovation Review Winter 2011, pp. 36-41.

Karatzoglou, B., 2013. An in-depth literature review of the evolving roles and contributions of universities to education for sustainable development. J. Clean. Prod. 49, 44-53.

Kates, R.W., Clark, W.C., Corell, R., Hall, J.M., Jaeger, C.C., Lowe, I., McCarthy, J.J., Schellnhuber, H.J., Bolin, B., Dickson, N.M., Faucheux, S., Gallopin, G.C., Grubler, A., Huntley, B., Jager, J., Jodha, N.S., Kasperson, R.E., Mabogunje, A.
Matson, P., Mooney, H., Moore III, B., O'Riordan, T., Svedin, U., 2001. Sustainability science. Science 292, 641-642.

Kezar, A., 2001. Understanding and Facilitating Organisational Change in the 21st Century: Recent Research and Conceptualisations (Special Issue), pp. 1-162. ASHE-ERIC Higher Education Report.

Kollmuss, A., Agyeman, J., 2002. Mind the gap: why do people act environmentally and what are the barriers to pro-environmental behavior? Environ. Educ. Res. 8, 239-260.

KPMG, 2013. The KPMG Survey of Corporate Responsibility Reporting 2013. KPMG International, p. 82.

KPMG, GRI, CCGA, UNEP, 2013. Carrots and Sticks: Sustainability Reporting Policies Worldwide - Today's Best Practice, Tomorrow's Trends. KPMG Advisory N.V., Global Reporting Initiative, Centre for Corporate Governance in Africa, United Nations Environment Programme, p. 96.

Kuhn, T.S., 1996. The Structure of Scientific Revolutions, third ed. The University of Chicago Press, Chicago and London.

Lang, D.J., Wiek, A., Bergmann, M., Stauffacher, M., Martens, P., Moll, P., Swilling, M., Thomas, C.J., 2012. Transdisciplinary research in sustainability science: practice, principles, and challenges. Sustain. Sci. 7, 25-43.

Lo, S.H., Peters, G.-J.Y., Kok, G., 2012. A review of determinants of and interventions for proenvironmental behaviors in organizations. J. Appl. Soc. Psychol. 42, 2933-2967.

Lozano, R., 2006a. Incorporation and institutionalization of SD into universities: breaking through barriers to change. J. Clean. Prod. 14, 787-796.

Lozano, R., 2006b. A tool for a graphical assessment of sustainability in universities (GASU). J. Clean. Prod. 14, 963-972.

Lozano, R., 2011. The state of sustainability reporting in universities. Int. J. Sustain. High. Educ. 12, 67-78.

Lozano, R., Ceulemans, K., Alonso-Almeida, M., Huisingh, D., Lozano, F.J., Waas, T., Lambrechts, W., Lukman, R., Hugé, J., 2015. A review of commitment and implementation of sustainable development in higher education: results from a worldwide survey. J. Clean. Prod. 108, 1-18.

Lozano, R., Lozano, F.J., Mulder, K., Huisingh, D., Waas, T., 2013a. Advancing higher education for sustainable development: international insights and critical reflections. J. Clean. Prod. 48, 3-9.

Lozano, R., Lukman, R., Lozano, F.J., Huisingh, D., Lambrechts, W., 2013b. Declarations for sustainability in higher education: becoming better leaders, through addressing the university system. J. Clean. Prod. 48, 10-19.

Lozano, R., Young, W., 2013. Assessing sustainability in university curricula: exploring the influence of student numbers and course credits. J. Clean. Prod. 49, 134-141.

Luthans, F., Avolio, B.J., 2009. The "point" of positive organizational behavior. J. Organ. Behav. 30, 291-307.

M'Gonigle, M., Starke, J., 2006. Planet U: Sustaining the World, Reinventing the University. New Society Publishers, Canada.

Manring, S.L., 2014. The role of universities in developing interdisciplinary action research collaborations to understand and manage resilient social-ecological systems. J. Clean. Prod. 64, 125-135.

Morphew, C.C., Hartley, M., 2006. Mission statements: a thematic analysis of rhetoric across institutional type. J. High. Educ. 77, 456-471.

Moses, J.W., Knutsen, T.L., 2012. Ways of Knowing: Competing Methodologies in Social and Political Research. Palgrave Macmillan.

Müller-Christ, G., Sterling, S., van Dam-Mieras, R., Adomßent, M., Fischer, D., Rieckmann, M., 2014. The role of campus, curriculum, and community in higher education for sustainable development - a conference report. J. Clean. Prod. 62, 134-137.

Oskamp, S., 2000. A sustainable future for humanity? How can psychology help? Am. Psychol. 55, 496-508.

Pfeffer, J., 2010. Building Sustainable Organizations the Human Factor. Academy of Management Perspectives, pp. 34-45.

Pielke Jr., R.A., 2007. When Scientists Politicize Science/Making Sense of Science in Policy and Politics, the Honest Broker: Making Sense of Science in Policy and Politics. Cambridge Univeristy Press, Cambridge.

Porter, M.E., Kramer, M.R., 2011. Creating Shared Value: how to reinvent capitalism and unleash a wave of innovation and growth. Harv. Bus. Rev. 64-77.

Posner, S.M., Stuart, R., 2013. Understanding and advancing campus sustainability using a systems framework. Int. J. Sustain. High. Educ. 14, 264-277.

Rockström, J., Steffen, W., Noone, K., Persson, Å., Chapin, F.S., Lambin, E.F., 2009. A safe operating space for humanity. Nature 461, 472-475.

Romanelli, E., Tushman, M.L., 1994. Organizational transformation as punctuated equilibrium: an empirical test. Acad. Manag. J. 37, 1141-1166.

Roorda, N., 2010. Sailing on the Winds of Change: the Odyssey to Sustainability of the Universities of Applied Sciences in the Netherlands. International Centre for Integrated assessment and Sustainable development. Maastricht University, Tillburg/Maastricht, p. 297.

Rotmans, J., 2006. Tools for integrated sustainability assessment: a two-track approach. Integr. Assess. J. 6, 35-57.

Scherer, A.G., Palazzo, G., Matten, D., 2009. Introduction to the special issue: globalisation as a challenge for business responsibilities. Bus. Ethics Q. 19, 327-347.

Schmuck, P., Vlek, C., 2003. Psychologists can do much to support sustainable development. Eur. Psychol. 8, 66-76.

Scholz, R.W., 2011. Environmental Literacy in Science and Society: from Knowledge to Decisions. Cambridge University Press, New York.

Sedlacek, S., 2013. The role of universities in fostering sustainable development at 
the regional level. J. Clean. Prod. 48, 74-84.

Shelley, A.R., 2013. Gauging Corporate Governance for Sustainability: Public-private Partnership in Accounting for Sustainable Development. Institutionen för Geovetenskaper. Uppsala University, Uppsala, Sweden, p. 58.

Simon, K., Haertle, J., 2014. Rio+20 higher education sustainability initiative (HESI) commitments - a review of progress, October 2014. In: UN Global Compact Principles for Responsible Management Education (PRME).

Söderbaum, P., 2008. Understanding Sustainability Economics: towards Pluralism in Economics. Earthscan, London.

Spangenberg, J.H., 2011. Sustainability science: a review, an analysis and some empirical lessons. Environ. Conserv. 38, 275-287.

Stacey, R.D., 2001. Complex Responsive Processes in Organisations: Learning and Knowledge Creation. Routledge, USA \& Canada.

Steffen, W., Sanderson, A., Tyson, P., Jäger, J., Matson, P., Moore, B.I., Oldfield, F., Richardson, C., Schellnhuber, J., Turner, B.L.I., Wasson, R., 2004. Global Change and the Earth System: a Planet under Pressure; Executive Summary. International Geosphere-Biosphere Program, Stockholm.

Steinfeld, H., Gerber, P., Wassenaar, T., Castel, V., Rosales, M., De Haan, C., 2006. Livestock's Long Shadow: Environmental Issues and Options. Food and Agriculture Organisation of the United Nations, Rome.

Stephens, J.C., Graham, A.C., 2010. Toward an empirical research agenda for sustainability in higher education: exploring the transition management framework. J. Clean. Prod. 18, 611-618.

Stephens, J.C., Hernandez, M.E., Román, M., Graham, A.C., Scholz, R.W., 2008. Higher education as a change agent for sustainability in different cultures and contexts. Int. J. Sustain. High. Educ. 9, 317-338.

Swim, J.K., Stern, P.C., Doherty, T.J., Clayton, S., Reser, J.P., Weber, E.U., Gifford, R. Howard, G.S., 2011. Psychology's contributions to understanding and addressing global climate change. Am. Psychol. 66, 241-250.

Sylvestre, P., McNeil, R., Wright, T., 2013. From Talloires to turin: a critical discourse analysis of declarations for sustainability in higher education. Sustainability 5, 1356-1371.

Trencher, G., Bai, X., Evans, J., McCormick, K., Yarime, M., 2014a. University partnerships for co-designing and co-producing urban sustainability. Glob. Environ. Change 28, 153-165.

Trencher, G., Yarime, M., McCormick, K.B., Doll, C.N., Kraines, S.B., 2014b. Beyond the third mission: Exploring the emerging university function of co-creation for sustainability. Sci. Public Policy 41 (2), 151-179.

Trevino, L.K., Weaver, G.R., Reynolds, S.J., 2006. Behavioral ethics in organizations: a review. J. Manag. 32, 951-990.

Turnpenny, J., Nilsson, M., Russel, D., Jordan, A., Hertin, J., Nykvist, B., 2008. Why is integrating policy assessment so hard? A comparative analysis of the institutional capacities and constraints. J. Environ. Plan. Manag. 51, 759-775.

UN, 2012. A Practical Guide to the United Nations Global Compact for Higher Education Institutions: Implementing the Global Compact Principles and Communicating on Progress. United Nations Global Compact Office, p. 24.

UNEP, 2013. In: Clayton, J. (Ed.), Greening Universities Toolkit: Transforming Universities into Green and Sustainable Campuses; a Toolkit for Implementers. United Nations Environment Programme, p. 54.

UNESCO, 2014. UNESCO Roadmap for Implementing the Global Action Programme on Education for Sustainable Development. United Nations Educational, Scientific and Cultural Organization, Paris, France, p. 37.

van der Heijden, A., Cramer, J.M., Driessen, P.P.J., 2012. Change agent sensemaking for sustainability in a multinational subsidiary. J. Organ. Change Manag. 25, 535-559. van der Voet, J., 2014. The effectiveness and specificity of change management in a public organization: transformational leadership and a bureaucratic organizational structure. Eur. Manag. J. 32, 373-382.

Velazquez, L., Munguia, N., Platt, A., Taddei, J., 2006. Sustainable university: what can be the matter? J. Clean. Prod. 14, 810-819.

Velazquez, L., Munguia, N., Sanchez, M., 2005. Deterring sustainability in higher education institutions: an appraisal of the factors which influence sustainability in higher education institutions. Int. J. Sustain. High. Educ. 6, 383-391.

Vos, R.O., 2007. Defining sustainability: a conceptual orientation. J. Chem. Technol. Biotechnol. 82, 334-339.

Voß, J.-P., Kemp, R., 2006. Sustainability and reflexive governance: introduction. In: Voß, J.-P., Bauknecht, D., Kemp, R. (Eds.), Reflexive Governance for Sustainable Development. Edward Elgar, Cheltenham, UK, Northampton, MA, USA.

Wallerstein, I., 1974. The Modern World System Academic Press, New York.

Warhurst, A., 2005. Future roles of business in society: the expanding boundaries of corporate responsibility and a compelling case for partnership. Futures 37 , $151-168$.

Waterman, H., Tillen, D., Dickson, R., Koning, K.d., 2001. Action Research: a Systematic Review and Guidance for Assessment. Health Technology Assessment, Basingstoke, UK.

Westley, F., Olsson, P., Folke, C., Homer-Dixon, T., Vredenburg, H., Loorbach, D. Thompson, J., Nilsson, M., Lambin, E., Sendzimir, J., Banerjee, B., Galaz, V., van der Leeuw, S., 2011. Tipping toward sustainability: emerging pathways of transformation. Ambio 40, 762-780.

Westley, F., Tjornbo, O., Schultz, L., Olsson, P., Folke, C., Crona, B., Bodin, Ö., 2013 A theory of transformative agency in linked social-ecological systems. Ecol. Soc $18,27$.

Wiek, A., Lang, D.J., 2016. Transformational sustainability research methodology. In: Heinrichs, H., Martens, P., Michelsen, G., Wiek, A. (Eds.), Sustainability Science. Springer, Netherlands, pp. 31-41.

Wiek, A., Ness, B., Schweizer-Ries, P., Brand, F.S., Farioli, F., 2012. From complex systems analysis to transformational change: a comparative appraisal of sustainability science projects. Sustain. Sci. 7, 5-24.

Wiek, A., Withycombe, L., Redman, C.L., 2011. Key competencies in sustainability: a reference framework for academic program development. Sustain. Sci. 6, 203-218.

World Commission on Environment and Development, 1987. Our Common Future. Oxford University Press, Oxford.

Yarime, M., Tanaka, Y., 2012. The issues and methodologies in sustainability assessment tools for higher education institutions: a review of recent trends and future challenges. J. Educ. Sustain. Dev. 6, 63-77.

Yarime, M., Trencher, G., Mino, T., Scholz, R.W., Olsson, L., Ness, B., Frantzeskaki, N. Rotmans, J., 2012. Establishing sustainability science in higher education institutions: towards an integration of academic development, institutionalization, and stakeholder collaborations. Sustain. Sci. 7, 101-113.

Young, I.M., 2006. Responsibility and global justice: a social connection model. Soc. Philos. Policy 23, 102-130.

Yuan, X., Zuo, J., 2013. A critical assessment of the Higher Education for Sustainable Development from students' perspectives - a Chinese study. J. Clean. Prod. 48, $108-115$.

Zadek, S., 2006. The Logic of Collaborative Governance: Corporate Responsibility, Accountability, and the Social Contract. Corporate Social Responsibility Initiative; John F. Kennedy School of Government; Harvard University.

Zeijl-Rozema van, A., Cörvers, R., Kemp, R., Martens, P., 2008. Governance for sustainable development: a framework. Sustain. Dev. 16, 410-421. 